\section{RELAPSING FEVER IN CYRENAICA}

BY

\author{
N. F. COGHILL, M.A., M.B., M.R.C.P. \\ Late Major, R.A.M.C.; Medical Specialist
}

\section{J. LAWRENCE, M.R.C.S., L.R.C.P.}

Late Captain, R.A.M.C.; Graded Physician

AND

\section{D. BALLANTINE, M.B., Ch.B. Late Captain, R.A.M.C.}

The objects of this paper are to describe four cases of relapsing fever seen in Cyrenaica, one of which was contracted in Benghazi, to discuss the relevant literature, and to bring to light some new information (not our own) regarding vectors of relapsing fever in Cyrenaica.

The pre-war Italian work on the disease in this area is worth noting. Vernoni ${ }^{1}$ was the first to describe a case of relapsing fever with positive blood film; this occurred in Barce ( $\mathrm{El} \mathrm{Merg}$ ). Medulla has contributed a number of articles on the subject. In 1931 he drew attention to various types of recurrent fevers in Cyrenaica, most of which, however, had negative blood films. ${ }^{2}$ In 1933 he described two cases, confirmed microscopically, which may have been infected in Benghazi ${ }^{3}$; and in 1934 he reported a further four cases which were infected while on military manœuvres in the Jebel, near Cyrene; only two of these appear to have had positive blood films. ${ }^{4}$ In 1935 he published three more cases from the same source, in only one of which were spirochaetes seen in the blood. ${ }^{5}$ In the same year he described a further well-proved case from Apollonia ; in this instance the attendant doctor accidentally pricked himself with an infected syringe needle and five days later developed relapsing fever with positive blood film. ${ }^{6}$ In 1937 Medulla reported a further three cases infected in Barce. ${ }^{7}$ It is of interest to note that most cases in British troops during the war came from around Tobruk. $^{8}$ 9

The following four cases were seen by us at 82 General Hospital in Benghazi.

\section{Case 1}

A Palestinian driver aged 21 had fever, headache, malaise, general aching, vomiting, cough, and constipation which started on April 30, 1944. He was admitted to hospital on May 3, when the temperature was $100.6^{\circ} \mathrm{F}$. $\left(38.1^{\circ} \mathrm{C}\right.$.). The liver was tender and enlarged one fingerbreadth below the right costal margin. The spleen was tender but doubtfully palpable. The axillary, inguinal, femoral, and epitrochlear lymph glands were tender and slightly enlarged, the tenderness in the axillary and inguinal regions being considerable. On May 4 the temperature was : morning, $102.4^{\circ} \mathrm{F} .\left(39.1^{\circ} \mathrm{C}.\right)$; evening, $104^{\circ} \mathrm{F}$. $\left(40^{\circ} \mathrm{C}.\right)$. The lymph glands were less tender and the abdominal tenderness had gone. A blood film revealed fairly numerous spirochaetes. There was much sweating. Next day the morning and evening temperatures were $102^{\circ} \mathrm{F}$. $\left(38.9^{\circ} \mathrm{C}\right.$.) and $104.2^{\circ} \mathrm{F}$. $\left(40.1^{\circ} \mathrm{C}\right.$.). The white cells numbered 6.000 per c.mm. (polymorphs, $85 \%$; lymphocytes, $10 \%$; monocytes, $4 \%$; eosinophils, $1 \%$ ). The blood films were again positive. Neoarsphenamine (N.A.B.), 0.6 g., was given intravenously. The temperature fell to normal by crisis the next morning and remained down. The lymph-gland tenderness had gone and the patient was feeling better. Further doses of 0.6 g. of N.A.B. were given intravenously on May 12 and 19. There was no relapse and convalescence was uneventful. The fever lasted six days, but he was never more than moderately ill.

This patient had not set foot outside Benghazi for a full month before the onset of his illness.

\section{Case 2}

An Italian P.O.W. aged 27 started to get vague abdominal discomfort, headache, and feverishness on June 13, 1944. He was admitted to hospital on June 15, when, apart from a temperature of $100.2^{\circ} \mathrm{F}$. $\left(37.9^{\circ} \mathrm{C}\right.$.), the only sign of disease was a spleen enlarged two fingerbreadths below the costal margin. There was no history of malaria. Early the next. day the temperature had risen to $104.2^{\circ} \mathrm{F}$. $\left(40.1^{\circ} \mathrm{C}\right.$.) (Chart 1), and spirochaetes were found in the blood; he was given $0.6 \mathrm{~g}$. of N.A.B. intravenously at once. The headache lasted one more day, but the fever persisted until June 21 (the ninth day of disease). On June 23 and 30 he received further doses of 0.6 g. of N.A.B. intravenously, but on June 25 a prolonged irregular pyrexia began which lasted until July 16 . Repeated blood slides during this period were negative. At first he complained only of intermittent headache, but by July 4 (the 22nd

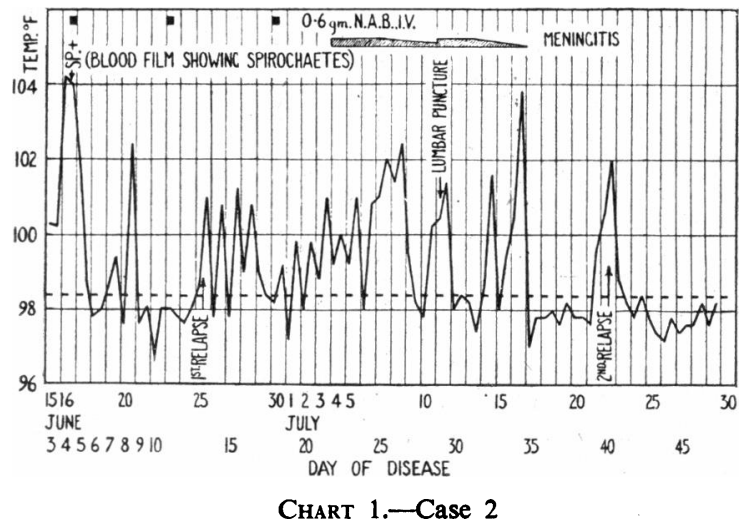

day) he was vomiting and the headache was severe. Two days later he was also drowsy and uncooperative. The white cell count was 9,600. After a short period of improvement vomiting recurred on July 11 , and there was again severe headache, now with moderate neck stiffness, but no Kernig sign. A lumbar puncture produced clear cerebrospinal fluid under a pressure of $180 \mathrm{~mm}$. of water, containing 600 cells (all lymphocytes) per c.mm.; protein, $180 \mathrm{mg}$. per $100 \mathrm{ml}$.; chlorides (as $\mathrm{NaCl}$ ), $700 \mathrm{mg}$. per $100 \mathrm{ml}$. ; no spirochaetes. Two days later he was much improved, but still complained of abdominal discomfort. He became symptomless by July 17, but on the 21 st the ophthalmologist reported mild bilateral papilloedema. There was further fever (second relapse), after which he remained well. The haemoglobin (Sahli) was $110 \%$ on Aug. 14. The splenic enlargement diminished but did not disappear.

This patient's movements during the incubation period are not known in detail, but he came from Western Cyrenaica.

\section{Case 3}

An Indian pioneer aged 25 first became ill with fever, headache, malaise, and constipation on June 14, 1944. He was admitted to hospital on June 16. The temperature was $100.2^{\circ} \mathrm{F}$. $\left(37.9^{\circ} \mathrm{C}\right.$.), later rising to $103.4^{\circ} \mathrm{F}$. $\left(39.7^{\circ} \mathrm{C}\right.$.), with a rigor during which spirochaetes were found in the blood. Lungs: cough with numerous generalized rhonchi, many expiratory. Abdomen: tenderness in the iliac fossae, pronounced on the right, but considered not appendicular. The symptoms and fever continued for another day-temperature $102^{\circ} \mathrm{F}$. $\left(38.9^{\circ} \mathrm{C}\right.$.). On June 17 N.A.B., 0.6 g., was given intravenously. The fever had gone by the next day, but the chest was not clear of signs until June 21. On June 19 the white cell count was 4,000 (polymorphs, 78\% ; lymphocytes, 15\% ; monocytes, 7\%). Further intravenous injections of $0.6 \mathrm{~g}$. of N.A.B. were given on June 24 and July 1 . There were no relapses and convalescence was rapid.

The movements of this patient during the incubation period could not be determined with accuracy, but they were wholly within Cyrenaica, and he had spent much of this time in Benghazi. 


\section{Case 4}

A British lance-corporal aged 33 had sudden onset of headache, malaise, aches in the limbs, feverishness, and sweating on June 19, 1944, and was admitted to hospital the same day. The temperature was $101^{\circ} \mathrm{F} .\left(38.3^{\circ} \mathrm{C}\right.$.) (Chart 2). There were no other signs of disease, and the blood films were negative. There was a rigor on the next day and he vomited. The first blood film to show spirochaetes was obtained on June 21, and the patient received $0.6 \mathrm{~g}$. of N.A.B. intravenously at once. The vomiting lasted one more day and the fever four days in all. The spleen became palpable on the last day of fever. There was no history of malaria. N.A.B., 0.6 g., was given intravenously on June 28 and July 5 . On the 5th began a low irregular fever lasting four days (first relapse); the spleen remained palpable and there was headache and much sweating. A three-day symptomless afebrile period followed, after which, beginning on July 13 (the 25th day of disease), there

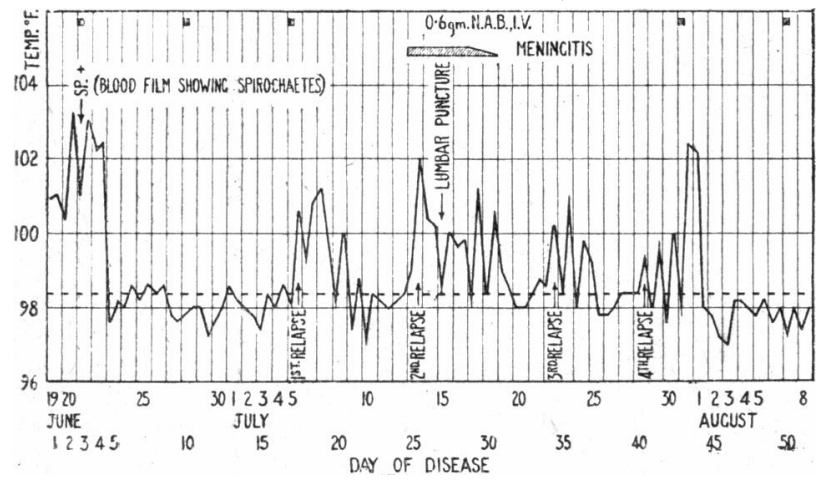

Chart 2.-Case 4

were six days of relatively low-grade fever (second relapse) Headache returned and worsened. On the 15 th there was mild neck stiffness. A lumbar puncture on this date produced a clear cerebrospinal fluid under a pressure of $250 \mathrm{~mm}$. of water, containing 40 cells (all lymphocytes) per c.mm.; protein, $45 \mathrm{mg}$. per $100 \mathrm{ml}$. (globulin not increased). A rabbit was inoculated with the cerebrospinal fluid but developed no infection. All symptoms had gone by July 19 . The optic fundi remained normal. A low fever developed on the $21 \mathrm{st}$ (third relapse) and lasted three days; this pyrexial bout was relatively symptomless. A fourth relapse began on July 28 and lasted four days. Thereafter recovery was uninterrupted. Two more injections of 0.6 g. of N.A.B. were given intravenously on July 31 and Aug. 7. On the last date the haemoglobin was $80 \%$ (Haldane). The spleen became impalpable during convalescence. Numerous blood films from July 6 onwards were all negative.

This patient spent two nights in a billet in Tobruk within the incubation period and may well have contracted the infection there. Otherwise his movements had been inside Benghazi only.

The following is a summary of the symptoms and signs in the four cases.

Abdomen.-Vomiting ( 3 cases); constipation (2); vague pain (1); spleen enlarged (2); spleen tender (1); liver enlarged (1); liver tender (1); tenderness in iliac fossae (1).

General.-Fever (4); prolonged irregular fever (1); headache (4) ; malaise (3) ; shivering (2) ; general aches and pains (2); cough (2); noticeable sweating (2); lung rhonchi (1); mild anaemia (1); lymph glands enlarged and tender (1); meningitis (2).

Meningitis.-Headache (2); neck stiffness (2); abnormal cerebrospinal fluid (2); vomiting (1); drowsiness (1); papilloedema (1).

Other Points.-Relapses: two cases had none ; one had two ; and one had four. Length of pyrexial attacks (all treated), 1-22 days. Length of apyrexial intervals, 2-12 days. Length of stay in hospital: Cases 1 and 3,20 days ; Case 2, 73 days ; Case 4, 69 days.
Spirochaetes were scanty in the blood films of Cases 2, 3, and 4 ; in Case 1 they were moderately plentiful. The effect of neoarsphenamine treatment was poor.

\section{Discussion}

It was not possible to carry out investigations to discover the species of spirochaete. However, none of the patients was lousy, and there was no reason to suppose that any had been in contact with lice. It can be assumed with a fair degree of certainty that the spirochaetes were tick-borne in origin, although it is just possible that in Case 1 they were louse-borne. The variation in the symptomatology and clinical courses of these four cases illustrates well the different forms that tick-borne relapsing fever can present. The rather long initial fever of Case 1 is more like the louseborne type. The high incidence ( 2 out of 4 ) and type of neurological complications and the poor response to treatment with intravenous arsenicals are consistent with the findings of others reporting relapsing fever from Cyrenaica and the Egyptian western desert, notably Medulla,; Cooper, ${ }^{10}$ Bulmer, ${ }^{11}$ Scott, ${ }^{12}$ McAlpine, ${ }^{13}$ and reports and publications by Army medical consultants, M.E.F. ${ }^{8} 1415$

The question of the vector in Cyrenaican relapsing fever is of some interest. The origin of the infection in Case 1 at least was Benghazi ; Case 4 very possibly contracted it in Tobruk, a well-known infective centre. ${ }^{8} 101314$ In Cyrenaica, as in America, Palestine, Southern Russia, and, more recently, Cyprus, ${ }^{16} 17$ the tick-borne disease, once recognized, will probably be found to be of wide potential if not actual distribution, corresponding to a wide scattering of Ornithodorus ticks capable of transmitting Spirochaeta duttoni. It is quite possible that louse-borne relapsing fever also occurs, serving to complicate the picture; the local inhabitants are frequently lousy. We have been informed by Major Walmsley that groups of nomadic Libyans in the hills of Cyrenaica periodically have minor epidemics of relapsing fever in their small communities. It is possible that this might be a result of camping in some spot infested with infective ticks; but such epidemics may be louse-borne or even mixed. Medulla ${ }^{3}$ spoke of "the endemic illness in the highland districts" which is " transmitted by lice and by different Ornithodorus found in Cyrenaica." Manson-Bahr ${ }^{18}$ states that the louse-borne infection is prevalent among the Bedouin Arabs of North Africa, especially in the winter months.

In most of the Italian papers reporting cases no indication or conjecture is given as to the source of the spirochaetes. But note was periodically made that patients had had no contact with lice. ${ }^{19}$ On clinical and epidemiological considerations Medulla ${ }^{4}$ thought that the four cases he reported in soldiers from the Cyrene Jebel were probably tick-borne; he suspected two Ornithodorus ticks known to be present in the district. In 1927 Lodato collected specimens of an argasid tick at Gadhames, Tripolitania. ${ }^{29}$ Franchini and Taddia, ${ }^{21}$ recording cases at Bardia of what was probably "tick-bite fever," reported the finding of " a new species of Ornithodorus that lives in grottoes, probably on small rodents." The ticks from both these collections were apparently first thought to be Ornithodorus lahorensis Neumann, but were identified by Maria Tonelli Rondelli as $O$. franchinii, n.sp. ${ }^{21} 22$

Parrot $^{23}$ described in detail a new Ornithodorus tick found in the Algerian Sahara; he named this tick $O$. foleyi, n.sp. Roubaud and Colas-Belcour ${ }^{24}$ described a new tick from French North Africa which they named $O$. delanoëi, n.sp. This tick was differentiated from $O$. foleyi Parrot and $O$. lahorensis. From a comparative study these authors came to the conclusion that $O$. foleyi Parrot and $O$. franchinii Rondelli were probably the 
same. However, Franchini ${ }^{25} 26$ thought they were different species and claimed that he first described the tick later called $O$. franchinii Rondelli in 1927. Warburton ${ }^{20}$ considers that $O$. franchinii is probably the same as Argas brumpti, Neumann, 1907, a tick which has characters of both Argas and Ornithodorus genera.

Garibaldi $^{27}$ summarized the geographical distribution of argasid ticks in Italian North Africa. He stated that Argas persicus (Oken) had been found at Benghazi, Kufra, Marada, Tobruk, and Tocra; $O$. savignyi Audouin at Augila, Kufra, Gialo, Giarabub, and Marada ; $O$. franchinii at Porto Bardia, Kufra, and Marsa Lucch (the latter being between Bardia and Tobruk, on the coast). He stated that $O$. moubata Murray and $O$. lahorensis had been found only in Tripolitania, although Franchini ${ }^{19}$ said that these two ticks had also been found in Cyrenaica. Previously Zavattari, ${ }^{28}$ Gaspare, ${ }^{29}$ and Franchini ${ }^{30}$ had engaged in a controversy as to the presence of $O$. moubata in Libyathat is, in Italian North Africa. Franchini ${ }^{31}$ stated that $O$. savignyi had not so far been found naturally infected with spirochaetes in Cyrenaica, but he was able to transmit $S p$. duttoni to white mice through nymphs of $O$. savignyi from Agedabia. However, Kirk ${ }^{32}$ states that in this tick the infection is not hereditary and that. O. savignyi has never been found infected in nature.

In a publication by G.H.Q., M.E.F., ${ }^{15}$ it is stated that relapsing fever is "not uncommon" in "all parts of the western desert." Dewar and Walmsley ${ }^{33}$ mentioned only ticks as vectors in the Egyptian western desert and in "Libya" (presumably they mean Cyrenaica). Stuart ${ }^{34}$ reported that the louse-borne type is said to be very prevalent in Libya - that is, Italian North Africa-and that the tick-borne form also occurs there. He also said that "three recognized carriers of the disease have been recorded from Libya-namely, O. moubata, O. savignyi, and $O$. lahorensis." We have been unable to find any evidence in the literature that the last-named should be incriminated as a vector in Cyrenaica. Indeed, in spite of a considerable volume of work performed with $O$. lahorensis in other parts of the world, although there are some confusing opinions, no one has ever produced reliable evidence that it can transmit any strain of relapsingfever spircchaete. ${ }^{24} 35-5189$ The same remarks apply, but with more force, to Argas persicus, a tick which in the past has been often wrongly spoken of as a transmitter of human spirochaetosis. ${ }^{32404951-71}$

It must be admitted that a study of the literature relating to relapsing fever in Italian North Africa leaves one with a rather confused picture as to the vectors responsible. No one, so far as we are aware, has ever inoculated human blood infected with Cyrenaican strains of relapsing-fever spirochaetes into laboratory animals in order to determine the vector (louse or tick). Little work on that aspect of the disease in this area has been possible during the war. Neither time nor facilities were available to us for laboratory or field work, and we know of only two collections of ticks made from this region during the war. One of these was at Tobruk in 1942 by Major Joe Bryant, R.A.M.C., and after leaving his hands this collection has not been traced. Bryant stated that his ticks were certainly Ornithodorus sp. The other collection consisted of one tick produced by a private soldier on admission to hospital in Tobruk with relapsing fever. The patient stated that the tick had bitten him, but there is no record of the time relation of bite to onset of fever ${ }^{88}$ This tick was sent at once to Prof. Adler, who informs us that during the war he also received two ticks from the Egyptian western desert, all three ticks being the same species. We are now informed by Prof. Adler and Dr. Theodor that all the ticks they received from the western desert were $O$. tholozani (syn. papillipes), Laboulbène and Mégnin. This is a new piece of evidence of considerable value. Hitherto $O$. tholozani had not been found west of Cyprus. ${ }^{16}$ Transmission experiments performed with these ticks showed the two ticks from the western desert to be free of infection, but the tick from Tobruk was proved to be naturally infected with relapsing-fever spirochaetes (Adler and Theodor-personal communication). ${ }^{88}$

A final point of much less importance may be raised. It must be remembered, especially in connexion with cases occurring in towns, that some evidence has been produced that bed-bugs (Cimex lectularius) ${ }^{496772-79}$ and dog-ticks (Rhipicephalus sanguineus) $^{80-87}$ may cause isolated cases of relapsing fever. However, the evidence for this is by no means conclusive. The former are widespread in North Africa, and the latter have been identified in numerous places in Cyrenaica. ${ }^{27}$

\section{Summary}

Four cases of relapsing fever, probably tick-borne, are described. All contracted the infection in Cyrenaica; one was infected in Benghazi.

Two of these cases were complicated by meningitis, one of which had papilloedema. In these and other respects the four cases were of similar clinical type to cases from this area described by other authors.

The relevant literature, especially the Italian, is discussed.

Before the war Italian workers claimed to have identified one possible and two known carriers of relapsing-fever spirochaetes in Cyrenaica: respectively-O. foleyi Parrot (syn. O. franchinii Rondelli), $O$. moubata Murray, and $O$. savignyi Audouin.

Recently Adler and Theodor have identified ticks collected from Tobruk and the Egyptian western desert during the war as $O$. tholozani, Laboulbène and Mégnin, and have shown the Tobruk tick to be naturally infected with relapsing-fever spirochaetes.

Our thanks are particularly due to Prof. S. Adler and Dr. O. Theodor, of Jerusalem, for their kindness in supplying information about the ticks from the western desert. Thanks are also due to Prof. P. A. Buxton, Prof. R. M. Gordon, Brig. S. Smith, late R.A.M.C., Col. J. S. K. Boyd, late R.A.M.C., Dr. R. Kirk, Sudan Medical Service, and Major J. M. Drennan, R.A.M.C., pathologist, for valuable help in compiling this paper.

\section{REFERENCES}

${ }^{1}$ Vernoni, G. (1929). Arch. ital. Sci. med. colon., 10, 536.

Medulla, C. (1931). Ibid., 12, 230.

(1933). Ibid. 14, 484

(1934). Ibid., 15, 335 .

(1935). Ibid., 16, 610

(1935). Ibid., 16, 755 .

(1937). Ibid., 18, 111 .

${ }^{8}$ Smith. S. Quarterly report (third quarter, 1942) by Consultant in Tropical Medicine, M.E.F.

9 Bulmer, E. (1943). Trans. roy. Soc. trop. Med. Hyg., 37, 225.

${ }^{10}$ Cooper, E. L. (1942). Med. J. Austral., 1, 635

11 Bulmer, E. (1943). British Medical Journal, 1, 374

12 Scott, R. B. (1944). Lancet, 2, 436.

${ }^{13}$ McAlpine, D. (1945). Proc. roy. Soc. Med., 39, 169.

14 Smith, S. Quarterly report (second quarter, 1942) by Consultant in Tropical Medicine, M.E.F.

${ }^{15}$ Notes on Nervous Diseases and Head Injuries in M.E., 2nd ed., March, 1943, p. 20. G.H.Q., M.E.F.

${ }^{16}$ Wood, R. C., and Dixon, K. C. (1945). British Medical Journal. 2. 526.

${ }^{17}$ Coghill, N. F., and Gambles, R. M. In preparation

18 Manson-Bahr. P. (1941). Lancet, 1, 253.

${ }^{9}$ Franchini, G. (1935). Med. Parasitol., Moscow, 4, 140 Abstracted in Rev. appl. Ent., ser. B. 1935, 23, 166.

${ }^{20}$ Warburton, C. (1932). Parasitology, 24, 558

${ }^{21}$ Franchini, G., and Taddia, L. (1930). Arch. ital. Sci. med. colon. 11, 453 .

${ }^{22}$ Rondelli. M. T. (1930). Boll. Zool., 1; 113. Abstracted in Rev. appl. Ent., ser. B, 1930, 18, 207.

${ }^{23}$ Parrot, L. (1928). Bull. Soc. Path. exot., 21, 520.

${ }_{24}^{4}$ Roubaud, E., and Colas-Belcour, J. (1931). Ibid., $24,948$.

${ }^{25}$ Franchini. G. (1932). Arch. ital. Sci. med. colon., 13, 449.

20 Franchini. (1932). Ibid., 13, 621.

${ }_{27}$ Garibaldi, M. (1935). Ibid., 16, 664. 
${ }^{28}$ Zavattari, E. (1934). Ibid., 15, 347.

${ }^{29}$ Gaspare, L. (1934). Ibid., 15, 353.

30 Franchini, G. (1934). Ibid., 15, 360.

31 (1935). Ibid., 16, 403 .

${ }^{32}$ Kirk, R. (1939). Ann. trop. Med. Parasit., 33, 125

${ }^{3}$ Dewar, H. A., and Walmsley, R. (1945). Lancet, 2, 630.

* Stuart, G. (1945). U.N.R.R.A. Hith. Div., Epidem. Inform. 'Bull. 1, 453.

${ }^{35}$ Pavlovskii, E. N., et al. (1929). "Animal Parasites and Some Parasitic Diseases of Man in Tadzhikistan." Leningrad Zool Mus. Acad. Sci. Abstracted in Rev. appl. Ent., ser. B, 1930, 18,5 .

${ }^{36}$ _ (1932). Trud. Sov. Izuch. proizvod. Sil. ser. Turkmen. Pt. 2, p. 79. Abstracted in Rev. appl. Ent., ser. B, 1933

${ }^{37}$ Khodukin, N. I., and Sofiev, M. S. (1932). Zasotz. Zdravookhran. Uzbek., 11, 63. Abstracted in Rev. appl. Ent., ser. B, 1935 23, 6.

${ }^{38}$ Kandelaki, S. P. (1935). Med. Parasitol., Moscow, 4, 65 Abstracted in Rev. appl. Ent., ser. B, 1935, 23, 163.

${ }^{39}$ Aluimov, A. Y. (1935). Parasites, Transmetteurs, anim. venimeux. Rec. Trav. 25th Anniv. Sci. Pavlovsky, 1909-34 Moscow, p. 54. Abstracted in Rev. appl. Ent., ser. B, 1936 24. 174.

40 Brumpht, E. (1935). Ibid., p. 41.

41 (1936). Ann. Parasitol., 14, 632

12 Pirumov, K. N. (1937). Med. Parasitol., Moscow, 6, 756 Abstracted in Rev. appl. Ent., ser. B, 1938, 26, 237.

43 Delpy, L., and Rafyi, A. (1939). Ann. Parasit. hum. comp., 17 45.

* Samsonov, P. F. (1926). Turkestansk. med. J., 4, 249. Abstracted in Rev. appl. Ent., ser. B, 1926, 14, 193.

45 Troitzkii, N. (1928). Mikrobiol. Zhurn., 2, Pt. 3 (abstract in Russian J. trop. Med., 6, 275). Abstracted in Rev. appl. Ent., ser. B. 1928, 16, 219.

${ }^{46}$ Bilal, S. (1939). Bull. Soc. Path. exot., 32, 872.

${ }^{47}$ Manson-Bahr, P. H. Manson's Tropical Diseases, 12th ed., 1935 p. 946, Cassell, London.

${ }^{4}$ Moursund, W. H. (1942). Publ. Amer. Ass. Adv. Sci., No. 18 p. 1 , ed. F. R. Moulton, Washington.

${ }^{49}$ Hindle, E. (1931). M.R.C. System of Bacteriology, 8, 164, H.M.S.O., London.

${ }^{50}$ Fairley, N."H. (1946). A Textbook of the Practice of Medicine ed. F. W. Price, 7th ed., p. 249, Oxford Univ. Press, London.

${ }^{31}$ Harold, C. H. H. (1922). J. R.A.M.C., 38, 398.

52 Sergent, E., and Foley, H. (1910). Ann. Inst. Pasteur, 24, 337.

${ }_{53}$ Balfour, A. (1920). British Medical Journal, 1, 97.

${ }^{54}$ Nicolle, C., Anderson, C., and Colas-Belcour, J. (1928). C. r. Acad. Sci., Paris, 187, 790.

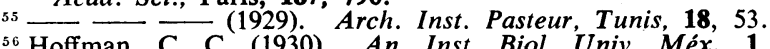
Abstracted in Rev. appl. Ent., ser. B, 1930, 18, 270.

Kirk R (1938) Ann. trop. Med Parasit., 32, 357

${ }_{58}^{57}$ Kirk, R. (1938). Ann. trop. Med. Parasit.

58 Sachs, A. (1934). J.R.A.M.C., 63, 217.

59 Wright, H. D., and Harold, C. H. H. (1920). Ibid., 35, 203

${ }^{60}$ Browse, G. V.' (1912). Indian med. Gaz., 47, 387.

${ }^{61}$ Nicholson, F. D. (1919). British Medical Journal, 2, 811.

${ }^{62}$ Dunlop, J. L. (1920). Ibid., 1, 132.

${ }_{63}$ Wenyon, C. M. (1926). Protozoology, 2, $1244 . \quad$ Baillière, Tindall and Cox, London.

${ }^{64}$ Adler, S.. Theodor, O., and Schieber, H. (1936). Lancet, 1, 448

${ }^{65}$ Patton, W. S., and Evans, A. M. (1929). Insects, Ticks, Mites etc., Liverpool Sch. Trop. Med., Pt. I, Medical, p. 622.

${ }^{6}$ Harold, C. T. H. H. (1920). J. R.A.M.C., 34, 484.

${ }^{67}$ Carlisle, R. J. (1906). J. infect. Dis., 3, 233.

${ }^{6}$ Sambon, L. W. (1905). British Medical Journal, 2, 1260.

${ }^{69}$ Calwell, W. K. (1920). Lancet, 2, 785.

${ }^{70}$ Balfour, A. (1920). British Medical Journal, 1, 235

Drake-Brockman, R. E. (1920). Ibid., 1, 273

"2 Francis, E. (1938). Publ. Hlth. Rep., Wash., 53, 2220

${ }^{3}$ Czarkowska, J., and Blank-Weissbeg, S. (1930). Med. Dośw. spol., 12, 110. Abstracted in Rev. appl. Ent., ser. B, 1930, 18, 223

Hindle, E. (1935). Trop. Dis. Bull., 32, 309.

${ }^{75}$ Strong, R. P. (1945). Stitt's Tropical Diseases, 1945, 7th ed., 1, 332, Lewis; London.

${ }^{76}$ Rosenholz, H. P. (1927). Zbl. Bakt., I. Abt. Orig., 102, 179. Abstracted in Trop. Dis. Bull., 1927, 24, 685.

- and Gilbert, M. J. (1927). Zbl. Bakt., I. Abt. Orig., 103, 348. Abstracted in Rev. appl. Ent., ser. B, 1927, 15, 210

McCulloch, W. E. (1925). J. trop. Med. Hyg., 28, 332.

${ }^{9}$ Kleine, F. K., and Krause, M. (1934). Arch. Schiffs- u. Tropenhyg., 38, 486. Abstracted in Trop. Dis Bull., 1935, 32, 297.

Sergent, A. (1933). C. r. Acad. Sci., Paris, 197, 717

${ }^{81}$ _- and Levy, H. (1935). Bull. Soc. Path. exot., 28, 789

${ }^{32}$ - (1938). Arch. Inst. Pasteur Algérie, 16, 403.

${ }^{83}$ Brumpt, E., and Caminopetros, J. (1936). Ann. Parasit. hum. comp., 14, 574

- (1936). Ibid., 14, 571

85 - (1936). Ibid., 14, 564.

${ }^{86}$ Chung, H. L. and Feng, L. C. (1938). Chin. med. J., March Supp. No. 2, p. 563 .

8: Boné, G. (1939). Ann. Soc. belge Méd. trop., 19, 477. Abstracted in Trop. Dis. Bull., 1940, 37, 641.

${ }^{83}$ Smith, S. (1942). Army medical conference, Cairo. Opening remarks in discussion on relapsing fever.

8? Pavlovsky, E. N., and Kuzmina, L. A. (1945). Med. Parasit. Parasitic Dis., 14, 66. Abstracted in Trop. Dis. Bull., 1946, 43, 744.

\section{TWO CASES OF FERROUS SULPHATE POISONING}

BY

JAMES THOMSON, M.B., F.R.C.P.

Paediatrician, Royal Infirmary, Dundee; Lecturer-in-Charge, Medical Diseases of Children, University of St. Andrews

After reading Dr. Gilbert Forbes's (1947) paper on poisoning with a preparation of iron, copper, and manganese I am prompted to record two further cases. It would seem that the condition may not be rare, and it is certainly one demanding increased precautions to prevent it.

\section{Case 1}

A 16-months-old girl was admitted to the Dundee Royal Infirmary on May 3,1944. About 10.30 a.m. on that date she obtained a packet of 40 tablets, each containing ferrous sulphate exsic. gr. $3(0.2$ g.) copper sulphate gr. $1 / 25(2.6 \mathrm{mg}$.), and manganese sulphate gr. 1/25. She swallowed all but one of these, and vomited almost at once, bringing up one tablet. Her mother gave her salt and water to drink, when about 12 more tablets were vomited. She thus retained about 26 of them. The child then became hot and drowsy and kept coughing and vomiting. The vomit contained mouthfuls of dark bloodstained materials.

She was admitted to hospital at 11.50 a.m. On examination she was rather pale, and was coughing and vomiting. The vomit was blood-stained. There was no rash or marked drowsiness. The temperature was $96^{\circ} \mathrm{F}$. $\left(35.6^{\circ} \mathrm{C}\right.$.), pulse 140 , and respirations 24 . The pulse was of slightly diminished volume. Her tongue was somewhat furred; the fauces were healthy. The abdomen was slightly distended. There was neither tenderness nor resistance on palpation. Nothing abnormal was noted in the central nervous system. Gastric lavage with a sodium bicarbonate solution was carried out, and brownish material was obtained. Some normal saline was left in the stomach. "Nepenthe" $1 / 2 \mathrm{~min}$. $\left(0.03 \mathrm{ml}\right.$.) was given at once, and $2 \frac{1}{2} \mathrm{gr}$. $(0.16 \mathrm{~g}$.) of bismuth carbonate was given four-hourly.

In the evening she was breathing heavily, but was otherwise comfortable. There was no cyanosis during the night. No vomiting occurred, but one loose stool containing mucus and dark blood was passed. The temperature rose suddenly to $101.2^{\circ} \mathrm{F} .\left(38.4^{\circ} \mathrm{C}\right.$.) at $7.30 \mathrm{a} . \mathrm{m}$. on the second day; her breathing became very difficult and she became cyanosed; she struggled, seemed to choke on inspiration, and died immediately.

Post-mortem Report (Dr. G. H. Smith).-A well-nourished female infant, rather cyanosed. Thorax: Heart and pericardium normal ; both lungs show areas of patchy collapse and rather oedematous mucopurulent material in bronchi and trachea ; no oedema of glottis. Abdomen: No free fluid in peritoneal cavity and no evidence of perforation. Stomach: Somewhat dilated. There is a large amount of brownish-black fluid present. The gastric mucosa is the seat of intense inflammatory change and there is a marked degree of necrosis and sloughing limited to the crests of the longitudinal rugae. Necrotic material from the stomach gives an intense iron reaction, the appearances being consistent with those due to corrosive poisoning. Numerous haemorrhagic points are apparent. Microscopical section shows necrosis of mucous membrane extending down to muscle. Intestines: Apart from a few patches of congestion in the upper jejunum, the intestines are healthy and the only contents present are black semi-fluid material resembling altered blood. Those contents are confined to the lower bowel, chiefly the pelvic colon. Liver: There is passive congestion. Neither hepatitis nor necrosis is present. Gall-bladder and pancreas: Healthy. Spleen: Healthy but congested. Kidneys and suprarenals: Healthy apart from venous engorgement. Ureter and bladder: Normal. Head: Brain and meninges healthy.

\section{Case 2}

A boy aged 2 years swallowed about 10 tablets similar to those mentioned above, about 9.30 a.m. on March 4, 1947. Approximately half an hour later he began to vomit green bile- 